\title{
A Review on Impact of Tillage and Nutrient Management on Maize Production in Indian Scenario
}

\author{
Amrendra Kumar* and Sunil Kumar
}

Department of Agronomy, TCA, Dholi, Dr. Rajendra Prasad Central Agricultural University, Pusa, Samastipur(Bihar), India

*Corresponding author

\section{A B S T R A C T}

\section{Keywords}

Tillage, Firbs, Bed Planting,

Subsoiling, SSNM, RDF

\section{Article Info}

Accepted:

06 August 2018

Available Online:

10 September 2018
Intensive tillage increases soil compaction, reduces soil aggregates stability, disrupts soil productivity, decreases retention and transportation of water and solutes and exacerbates losses due to run-off erosion. In contrast conservation agriculture like zero-till and minimum tillage (reduced tillable) increased porosity, organic carbon, water holding capacity and decreases bulk density. The FIRBS and ridge bed planting system improves soil environment for better plant and growth development with minimum requirement of irrigation water. Sub-soiling again a newly introduced intervention to break down the hard pan for improving field drainage and provides better soil tilth. The farmers often apply very high dose of nitrogen in form of urea and very little phosphorous and potassium and almost nil secondary and micronutrients leading to imbalance, toxicity as well as inadequate use of nutrients with reduce nutrient use efficiency and profitability. The intervention on plant nutrition's like site-specific nutrient management and recommended dose of fertilizer based on proper field experimentations and crop response, covering special variability in indigenous nutrient supplying capacity of are urgently required.

\section{Introduction}

Maize (Zea mays L.) is an important cereal crop for food, feed and fodder. It is not only an important food crop for human but also a basic element of animal feed, fodder and raw material for manufacturing of many industrial products. The industrial products include mainly corn starch, malto-dextrins, corn oil, corn syrup and products of fermentation and distilleries. It is also being recently used in the production of biofuel. Therefore, owing to its various uses, maize is known as a 'Queen of Cereals'. In term of area, maize is the third most important staple food crop in the world after wheat and rice but in term of productivity, it ranks first followed by rice, wheat and other millets. In India, maize is cultivated on 8.69 million hectare area with production and productivity of 21.81 million tonnes and $2509 \mathrm{~kg} / \mathrm{ha}$, respectively (Agriculture Research Data Book, ICAR, 2017).

Food security is major concerned of India. Maize may survive better and produce more than other crops under deficient soil moisture conditions. At present, it is difficult to 
increase acreage as well as irrigation because of stiff competition among different sectors; therefore to enhance the crop productivity is the only option to increase food and nutritional security of the country. Therefore different interventions like production of hybrids and genetically modified crops, development of climate resilient crops and varieties, adoption of different tillage systems, improving site specific plant nutrition, integrated pest and diseases management, post-harvest technologies, protective agriculture, application of organized remotesensing and GIS, nanotechnology, microbiology, biotechnology etc. are to be looked into the increase the crop productivity.

Tillage has been an integrated component of all crops mainly because it provides good soil tilth, improves water holding capacity, increase aeration and also moderates soil hydraulic conditions (Karami et al., 2012). The increasing demand of agricultural production including food, feed and fodder has changed our traditional agriculture to intensive agriculture that includes intensive tillage, heavy application of chemicals, water, labor, reduced the soil fertility and productivity. The research findings also confirmed that intensive tillage increases soil compaction, reduces soil aggregates stability, disrupts soil productivity, decreases retention and transportation of water and solutes and exacerbates losses due to run-off erosion (Goddard et al., 2008). In contrast many beneficial effects of no-till/zero-till and minimum tillage have also been reported like increased porosity, organic carbon, water holding capacity and decreases bulk density. Similarly, the FIRBS and ridge bed planting system have also been reported very beneficial for improving soil environment for better plant and growth development with minimum requirement of irrigation water. Sub-soiling is again a newly introduced intervention to break down the hard pan for improving field drainage and provides better soil tilth. The paradigm shift in tillage options like minimum tillage, zero tillage, FIRBS, raised bed planting has been observed world over. Due to the availability of herbicides, insecticides and fungicides and also more mechanization, the farmers prefer new tillage options compared to conventional tillage that is required mainly for seedbed preparation and weed control (Mohanty et al., 2006). The research findings have confirmed that minimum tillage increases aggregate stability Rusu (2005), zero tillage also promotes high aggregate stability, decreases soil temperature and maintains high carbon and nitrogen (Irizar et al., 2013). Zero tillage also reduces weed population in wheat (Sen et al., 2002). The cost of cultivation, irrigation and nutrient requirement in rice-wheat system are reduced under FIRBS and raised bed planting systems (Naresh et al., 2009) and increased soil quality (Goverts et al., 1999). The sub soiling is an urgent need to break the hard pan and also improve the soil porosity and percolation. Therefore, some of the research findings have already indicated that the sub soiling may be beneficial to improve the productivity and profitability of the system compared to adopting conventional tillage system.

It is a general practice in our country to provide blanket fertilizer recommendation for production of different crops. Different field surveys have also revealed that the farmers of Indo-Gangetic plains of India often apply very high dose of nitrogen in form of urea and very little phosphorous and potassium and almost nil secondary and micronutrients (Sing et al., 2014) leading to imbalance, toxicity as well as inadequate use of nutrients with reduce nutrient use efficiency and profitability. In addition, it increases environment risk associated with loss of unutilized nutrient through emission or leaching (Pampolino et al., 2012). Therefore, the intervention on plant nutritions like site- 
specific nutrient management and recommended dose of fertilizer based on proper field experimentations and crop response, covering special variability in indigenous nutrient supplying capacity of soil (Majumdar et al., 2013) are urgently required.

\section{Growth attributes of maize crops under different tillage system}

Memon et al., (2013) reported that deep tillage produced highest seedling emergence percentage while Khan et al., (2008) reported that minimum tillage and conventional tillage had higher seedling emergence percentage. Memon et al., (2013) observed that deep tillage produced tallest plant while Khan et al., (2008) found taller plants under minimum tillage and conventional tillage and also reported that maximum number of leaves observed under conventional tillage as compared to deep tillage and zero tillage. Memon et al., (2013) reported that deep tillage produced highest dry matter than the conventional tillage whereas Singh et al., (2012) revealed that dry matter and leaf area index were minimum in sub soiling, while Khan et al., (2008) observed that minimum tillage and conventional tillage had higher biomass and leaf area index. Hakim et al., (2011) reported that both maize and cotton crops produced higher leaf area index under permanent bed planting than conventional bed planting. Akbarnia et al., (2010) reported that reduced tillage achieved highest dry mass compared to conventional and no-till.

\section{Yield and yield attributes of maize crops under different tillage system}

Memon et al., (2013) reported that deep tillage produced highest grain yield than conventional tillage. Singh et al., (2012) reported that cob length was reduced by 13-16 per cent due to subsoil compaction in conventional tillage. Khan et al., (2008) reported that minimum tillage and conventional tillage had higher grains per cob, 1000-grain weight, biological yield as compared to deep tillage whereas, ridge planting produced maximum no. of cobs per plant, no. of grain and biological yield (Bakht et al., 2006). Singh et al., (2012) reported that grain yield was reduced by 10-17 per cent due to subsoil compaction while, Shah et al., (2014) reported that deep tillage observed higher grain yield (7.24 ton/ha) than conventional tillage and minimum tillage. Khan et al., (2008) reported that minimum tillage and conventional tillage had higher grain yield compared to deep tillage. Hakim et al., (2011) also noticed that maize and cotton crops produced 8 and $24 \%$ higher yield under permanent bed planting (PB) than conventional bed planting (CB), respectively and it was also supported by Bakht et al., (2006).

\section{Nutrient uptake of maize crops under different tillage system}

Tolessa et al., (2000) reported that N uptake was consistently superior with MTRR (minimum tillage with residue retention) compared to MTRV (minimum tillage with residue removal) and $\mathrm{CT}$ (Conventional tillage).

\section{Physico-biological properties of maize crops under different tillage system}

Mathew et al., (2013) reported that the longterm no-tillage corn resulted in higher soil carbon and in higher phosphatase activities at the $0-5 \mathrm{~cm}$ depth than the conventional tillage. Senjobi et al., (2013) reported that traditional tillage system observed lower bulk density followed by conventional and no-tillage while, Ji1 et al., (2013) observed that deep tillage had lower soil bulk density but higher soil water content than conventional tillage and they also reported that deep tillage had 
lower penetration resistance but higher soil water content than conventional tillage. Hakim et al., (2011) reported that soil organic matter (SOM) was significantly higher in permanent bed system due to higher SOM in the $0-0.05 \mathrm{~m}$ layer, particularly in the furrows. Moraru et al., (2010) revealed that soil moisture was higher in no tillage and minimum tillage. Garcia et al., (2006) reported that no-tillage decreased cation exchange capacity (CEC) and soil $\mathrm{pH}$ as compared with $\mathrm{MB}, \mathrm{CH}$, and $\mathrm{CT}$ in the 0 - to 50-mm soil layer.

\section{Growth attributes of maize crops under different nutrients management}

Singh et al., (2012) reported that each successive increase in nitrogen level from 0 to $120 \mathrm{~kg} /$ ha significantly improved plant height but remained at par with $150 \mathrm{~kg}$ N/ha. Meena et al., (2012) reported that treatment receiving $\mathrm{N}_{90} \mathrm{P}_{20} \mathrm{~K}_{25}+$ Bio-Compost equivalent to $30 \mathrm{~kg}$ $\mathrm{N} /$ ha being at par to $\mathrm{N}_{120} \mathrm{P}_{26} \mathrm{~K}_{33}$ recorded maximum plant height $(151.8 \mathrm{~cm})$. Singh et al., (2010) concluded that application of $125 \%$ recommended dose of fertilizers (RDF) gave significantly higher plant height of baby corn. Nadeem et al., (2009) reported that 150 $\mathrm{kg} \mathrm{N} /$ ha produced significantly more number of leaves per plant than the other nitrogen levels (0,50 and $100 \mathrm{~kg} \mathrm{~N} / \mathrm{ha})$. Meena et al., (2012) reported that treatment receiving $\mathrm{N}_{90} \mathrm{P}_{20} \mathrm{~K}_{25}+$ Bio-Compost equivalent to $30 \mathrm{~kg}$ $\mathrm{N} /$ ha being at par to $\mathrm{N}_{120} \mathrm{P}_{26} \mathrm{~K}_{33}$ recorded maximum LAI while Amanullah et al., (2009) reported that higher leaf area of maize with application of $50 \%$ higher $\mathrm{N}$ rate $(180 \mathrm{~kg} / \mathrm{ha})$ than the recommended rate $(120 \mathrm{~kg} / \mathrm{ha})$ in four to five splits. Kumar et al., (2014) reported that maize genotypes ' $\mathrm{CMH} \mathrm{08-292'}$ recorded significantly highest dry-matter accumulation at various stages as compared to 'PMH 1' due to SSNM over RDF. Singh et al., (2012) concluded that each successive increase in nitrogen level from 0 to $120 \mathrm{~kg} / \mathrm{ha}$ significantly improved dry weight/plant, however application of $150 \mathrm{~kg} \mathrm{~N} / \mathrm{ha}$ was at par with $120 \mathrm{~kg} \mathrm{~N} / \mathrm{ha}$. Meena et al., (2012) reported that treatment receiving $\mathrm{N}_{90} \mathrm{P}_{20} \mathrm{~K}_{25}+$ Bio-Compost equivalent to $30 \mathrm{~kg} \mathrm{~N} / \mathrm{ha}$ being at par to $\mathrm{N}_{120} \mathrm{P}_{26} \mathrm{~K}_{33}$ recorded maximum dry matter accumulation (67.7g/plant). Abbas et al., (2005) noticed increasing rate of nitrogen application up to $300 \mathrm{~kg} \mathrm{~N} / \mathrm{ha}$ increased crop growth rate in maize. Haq and Hamid (1998) also reported increased crop growth rate (CGR) with increase in nitrogen rate up to $150 \mathrm{~kg} \mathrm{~N} / \mathrm{ha}$ in maize.

\section{Yield and yield attributes under nutrients management}

Yadav et al., (2016) evaluated the effect of integrated nutrient management on productivity of maize with inter cropped mungbean. The result of experiment showed yield attributes and maize equivalent yield were higher at $5 \mathrm{t} / \mathrm{ha}$ vermicompost $+75 \%$ recommended dose of N.P.K. It gave higher maize equivalent yield over other treatments. In case of cropping systems, maize + mungbean recorded significantly higher grain yield over sole maize. Nsanzabaganwa et al., (2014) evaluated the impact of $\mathrm{N}$ and $\mathrm{P}$ independently and interactively on winter maize. Maize yield was highest at $240 \mathrm{~kg} \mathrm{~N} /$ ha. Phosphorus application increased yield up to $26.4 \mathrm{~kg} / \mathrm{ha}$ and combination of $240 \mathrm{~kg} \mathrm{~N} /$ ha and $26.4 \mathrm{~kg} \mathrm{P} / \mathrm{ha}$, providing highest gross returns, net returns and net benefit: cost. Application of PSB biofertilizer @ 2 kg ha-1 + humic acid @ $10 \mathrm{~kg} / \mathrm{ha}$ increased the biological yield, grain yield, stover yield and harvest index by 28, 50, 18 and 22\% respectively as compared to control (Baloach et al., 2014). Nagavani and Subbian (2014) reported that grain and stover yield of hybrid maize were recorded higher with the application of 50 per cent RDF through poultry manure +50 per cent RDF through inorganic fertilizers followed by 50 per cent 
RDF through vermicompost +50 per cent RDF through inorganic fertilizers. Islam and Munda (2012) reported that application of FYM $2.5 \mathrm{t} /$ ha + Alnus $2.5 \mathrm{t} /$ ha recorded maximum grain yield of maize and system productivity as compared to FYM $2.5 \mathrm{t} / \mathrm{ha}+$ Eupatorium 2.5 t/ ha. Gupta et al., (2014) reported the highest yield and yield components of maize crop with $100 \%$ recommended fertilizer dose $+\mathrm{ZnSO}_{4} @ 20$ $\mathrm{kg} / \mathrm{ha}$ and the grain yield was about $101 \%$ higher over the control. Kumar et al., (2013) reported that maize-genotypes ' $\mathrm{CMH} \mathrm{08-292'}$ recorded significantly highest cob yield with site-specific nutrient management (SSNM) over the recommended dose of fertilizer RDF as compare to PMH. Gupta et al., (2014) evaluated residual effect of organic and inorganic fertilizers in maize crop under maize-gobhisarson cropping sequence. The experiment was conducted with 10 treatments of $\mathrm{N}, \mathrm{P}, \mathrm{K}$ and FYM, crop residue and zinc sulphate nutrients and they reported that the highest growth and yield of maize was recorded under $100 \%$ recommended dose of fertilizers + $\mathrm{ZnSO}_{4} @ 20 \mathrm{~kg} / \mathrm{ha}$. Kannan et al., (2013) studied the effect of integrated nutrient management on soil fertility and productivity on maize and took six different treatments and reported that INM practice including vermicompost and recommended dose of NPK showed its best results with respect to leaf area and plant height as compared to other treatments. Choudharya and Kumar (2013) reported better growth parameters at application of vermicompost compared to other treatments. The Grain yield was increased under SSNM over RDF and FFP was about $17 \%$ and $28.6 \%$, respectively in maize, $12 \%$ and $24 \%$ in rice, $17.7 \%$ and $32.8 \%$ in wheat and $22.4 \%$ and $35.7 \%$ in rabi Jowar. In commercial crops, SSNM enhanced the seed cotton yield to the extent of $15.2 \%$ and $27 \%$ over RDF and FFP respectively, while the dry chilli yield increased by $12.8 \%$ and $23.6 \%$ as against the RDF and FFP. The grain yield of sunflower and chickpea under SSNM were higher by $20.9 \%$ and $34.8 \%$ and $19.6 \%$ and $26.4 \%$ respectively over RDF and FFP (Biradar et al., 2012). Hammad et al., (2011) recorded maximum grain yield of maize under $250 \mathrm{~kg} \mathrm{~N} / \mathrm{ha}$, while the highest biological yield was recorded at application of $300 \mathrm{~kg} \mathrm{~N} / \mathrm{ha}$. Mahesh et al., (2010) reported that combined application of recommended dose of NPK (150:75:40 kg/ha) + FYM 10 t/ha recorded higher grain yield (65.9 q/ha) followed by $75 \%$ recommended through nitrogen fertilizers and $25 \%$ nitrogen through poultry manure being at par with each other. The lowest grain yield was noticed in the treatment receiving 100 per cent recommended dose of NPK through chemical fertilizer $(150: 75: 40 \mathrm{~kg} / \mathrm{ha}$. Increase $\mathrm{N}$ rates enhanced crop productivity as maximum grain yield was recorded from plots fertilized with $300 \mathrm{~kg} \mathrm{~N} / \mathrm{ha}$ (Abbas et al., 2005). Similarly, the maximum grain yield (11.6 t/ha) was reported from the plot fertilized with $268 \mathrm{~kg} \mathrm{~N} / \mathrm{ha}$ in site-specific management zone (Inman et al., 2005). Arif et al., (2010) observed that grains/ear increased with increase in $\mathrm{N}$ level from 80 to $160 \mathrm{~kg} / \mathrm{ha}$ but the $\mathrm{N}$ level of 120 and $160 \mathrm{~kg} / \mathrm{ha}$ were statistically at par with each other so that they reported that better ear characters were obtained with $\mathrm{N}$ application of $120 \mathrm{~kg} / \mathrm{ha}$ and also supported by (Onasanya et al., 2009). Wasaya et al., (2011) observed the highest grain weight per cob at $200 \mathrm{~kg} / \mathrm{ha}$. The highest improvement in yield attributes and baby corn yield were recorded with the application of $120 \mathrm{~kg} \mathrm{~N} / \mathrm{ha}$ in two equal splits at sowing and knee high stages (Das et al., 2009, Bindhani et al., 2007 and Pandey et al., 2000). Kannan et al., (2013) studied the effect of integrated nutrient management on soil fertility and productivity on maize and they took six different treatments. INM practice including vermicompost and recommended dose of NPK showed its best results with respect to yield parameters like number of grains per 
cob, 100 seed weight and yield but the cob weight was recorded maximum under INM practice including FYM and recommended dose of NPK. Shah and Kumar (2014) evaluated the direct and residual effect of integrated nutrient management practices on hybrid rice and succeeding wheat. Integrated nutrient management showed significant influence on productivity on wheat. Residual effect of NPK 50\% RDF +FYM @5 tonnes/ ha + Azotobacter + Neem cake @ 2.5 tonnes/ ha+PSB@5 kg/ ha, recorded the highest grain yield of maize. Randhawa et al., (2012) reported that the crop applied with six irrigations and fertilized with integrated application of chemical fertilizers (250-120$\left.125 \mathrm{~kg} \mathrm{~N}-\mathrm{P}_{2} \mathrm{O}_{5}-\mathrm{K}_{2} \mathrm{O} / \mathrm{ha}\right)$ and farmyard manure (15 t/ ha) produced the highest grain yield, number of cobs/ plant, number of grain rows/cob, number of grains/ cob, 1000-grain weight, grain weight /cob, stover yield and biological yield.

\section{Physico-biochemical properties of soil under nutrients management}

Janwal (2006) reported that application of farmyard manure (FYM) increased significantly the available $\mathrm{N}, \mathrm{P}$ and $\mathrm{K}$ status of the soil after maize harvest. The available $\mathrm{P}$ status of the soil also increased significantly due to the residual effect of FYM and fertility levels. Kannan et al., (2013) reported that bulk density and pore space were recorded maximum in INM practice including vermicompost and recommended dose of NPK and also particle density but organic carbon was recorded maximum in FYM application. Choudharya and Kumar (2013) conducted an experiment with six treatments viz., vermicompost, poultry manure, swine manure, cow dung manure, farm yard manure and control to study the effect of applied organic nutrients on growth and yield attributes of maize and reported that the physical parameters like porosity, maximum water holding capacity (MWHC), field capacity (FC), permanent wilting point (PWP), bulk density (BD) and moisture releasing pattern were recorded higher when the crop was supplied with FYM followed by cow dung manure. Similarly chemical parameters like $\mathrm{pH}$, soil organic carbon (SOC), available nitrogen $(\mathrm{N})$, phosphorus $(\mathrm{P})$ and potassium $(\mathrm{K})$ were recorded better under vermicompost followed poultry manure over control. The poultry droppings mixed with burnt rice husk dust (PBRHD), cow dung mixed with unburnt rice husk dust (CURHD), goat dung mixed with sawdust (GSD) and NPK 20:10:10 fertilizer had significantly higher effect on total porosity, hydraulic conductivity, gravimetric moisture content (GMC) relative to control (Nwite et al., 2014). Application of $25 \%$ recommended dose of fertilizers (RDF) +biofertilizers (Azotobacter chroococcum + phosphate solubilizing bacteria)+ green manuring (with sunhemp) + compost @ 10 t/ha improved soil physico- chemical properties (viz. decrease in alkaline $\mathrm{pH}$ by 0.4 , bulk density by 0.04 $\mathrm{g} / \mathrm{cm}^{3}$ and increased infiltration rate by 0.65 $\mathrm{cm} / \mathrm{hr}$ ) and also improved the organic carbon, available $\mathrm{N}$ and available $\mathrm{P}_{2} \mathrm{O}_{5}$ which were increased by $0.14 \%, 4.4 \mathrm{~kg} / \mathrm{ha}$ and $11.7 \mathrm{~kg} / \mathrm{ha}$, respectively over the initial nutrient status of soil Kalhapure et al., 2013). Shilpashree et $a l$. , (2012) reported that the available nitrogen was recorded lower under chemical fertilizers than the organic matter application.

\section{Nutrient uptake under nutrients management}

Shah and Kumar (2014) found that integrated nutrient management had significant influence on nutrient uptake in wheat. The residual effect of NPK 50\% RDF +FYM @5 tonnes/ ha + Azotobacter + Neem cake @2.5 tonnes/ ha + PSB@ $5 \mathrm{~kg} / \mathrm{ha}$, recorded the highest for $\mathrm{N}, \mathrm{P}$ and $\mathrm{K}$ uptake by succeeding wheat crop. Choudharya and Kumar (2013) 
reported that the uptake of nitrogen, phosphorus and potassium was higher at application of vermicompost followed by poultry manure, whereas least nutrients were taken up at control. Parmasivan et al., (2012) reported that the highest total $\mathrm{N}$ and $\mathrm{Zn}$ uptake were observed from the application of 250-76-88-7.4 kg N-P-K-Zn / ha). Rehman et al., (2011) studied various doses of nitrogen and reported the highest nitrogen uptake efficiency with $250 \mathrm{~kg} \mathrm{~N} / \mathrm{ha}$ fertilizer dose and proved to be a good indicator of grain yield, however, the higher dose decreased NUE (300 kg N/ha) whereas Oktem et al., (2010) observed highest nitrogen use efficiency at $320 \mathrm{~kg} \mathrm{~N} / \mathrm{ha}$ and decrease was seen at $360 \mathrm{~kg} \mathrm{~N} / \mathrm{ha}$ dosage.

Mahesh et al., (2010) reported that combined application of recommended dose of NPK $(150: 75: 40 \mathrm{~kg} / \mathrm{ha})+\mathrm{FYM} 10 \mathrm{t} / \mathrm{ha}$ recorded higher nitrogen, phosphorus and potassium uptake (160.8, 41.9 and $77.8 \mathrm{~kg} / \mathrm{ha}$, respectively) followed by $75 \%$ recommended through nitrogen fertilizers and $25 \%$ nitrogen through poultry manure both were at par with each other. Higher nitrogen, phosphorus and potassium uptake respectively were also noticed under receiving 100 per cent recommended dose of NPK through chemical fertilizer (150:75:40 kg/ha). Inman et al., (2005) reported that nitrogen uptake and grain yield response to applied nitrogen was found to be statistically significant at $250 \mathrm{~kg} \mathrm{~N} / \mathrm{ha}$. Tolessa et al., (2000) reported that higher grain $\mathrm{N}$ content was recorded with MTRR than with MTRV and CT. The grain, stover and total biomass $\mathrm{N}$ uptake were consistently superior with MTRR compared to MTRV and CT. The agronomic (NAE), recovery (NRE) and physiological (NPE) efficient use of applied $\mathrm{N}$ by maize for the same tillage system were consistently higher at the lower $\mathrm{N}$ level range of $69-92 \mathrm{~kg} /$ ha than higher $\mathrm{N}$ level range of $92-115 \mathrm{~kg} / \mathrm{ha}$. The maximum Zn uptake, viz., $250.7 \mathrm{~g} / \mathrm{ha}$ was observed with
$75 \% \mathrm{~N}+25 \% \mathrm{CF}+\mathrm{FYM})$ and $4 \mathrm{~kg} \mathrm{Zn} / \mathrm{ha}$ application. The study also revealed that substitution of 25 or $50 \% \mathrm{~N}$ with FYM $+4 \mathrm{~kg}$ $\mathrm{Zn} /$ ha performed better than $100 \% \mathrm{~N}$ fertilizer alone, and had better leaf area index, grain and straw yield, soil organic matter content and nutrient uptake (Sarwar et al., 2012). Islam and Munda (2012) studied the effect of organic and inorganic on growth, productivity and nutrient uptake performance of maizetoria cropping system.

\section{Economics under nutrients management}

Yadav et al., (2016) found that maize equivalent yield, net return and $\mathrm{B}$ : $\mathrm{C}$ ratio was significantly higher at $5 \mathrm{t} /$ ha vermicompost $+75 \%$ recommended dose of N.P.K. The maize + mungbean cropping system gave higher maize equivalent yield, net return and B: C ratio followed by sole maize, respectively. Nsanzabaganwa et al., (2014) studied the impact of $\mathrm{N}$ and $\mathrm{P}$ independently and interactively on winter maize. Maize yield was highest at $240 \mathrm{~kg} \mathrm{~N} / \mathrm{ha}$, but was significantly at par with $160 \mathrm{~kg} \mathrm{~N}$. Every kg $\mathrm{N}$ applied produced $44.34 \mathrm{~kg}$ grain, and the $\mathrm{N}$-use efficiency was reduced with increased $\mathrm{N}$ dose. Phosphorus application increased yield up to $26.4 \mathrm{~kg} / \mathrm{ha}$. A combination of 240 $\mathrm{kg} / \mathrm{N}$ ha and $26.4 \mathrm{~kg} / \mathrm{P}$ ha, providing highest gross returns, net returns and net benefit: cost. The economic optimum dose for $\mathrm{N}$ and $\mathrm{P}$ was $196 \mathrm{~kg} \mathrm{~N} /$ ha and $23.4 \mathrm{~kg} \mathrm{P} / \mathrm{ha}$, respectively. Shah and Kumar (2014) reported that maximum mean net returns (Rs 87297.5/ha) and $\mathrm{B}$ : C ratio (1.6) under NPK 50\% RDF + FYM @ 15 tonnes/ha. Kalhapure et al., (2013) reported that application of $25 \%$ recommended dose of fertilizers (RDF) in combination with biofertilizers (Azotobacter chroococcum + phosphate solubilizing bacteria), green manuring with sunhemp and incorporation of compost @ 10 t/ha gave the highest gross return and net return. The B: C ratio was higher at $25 \% \mathrm{RDF}+$ compost+ 
biofertilizers + green manuring followed by application of $100 \%$ RDF which was responsible for deterioration of nutrient status of soil. Choudharya and Kumar (2013) reported that the gross and net return was higher at application of vermicompost followed by poultry manure whereas B: C ratio was recorded higher at poultry manure followed by cow dung manure. However, the lowest economic returns were recorded under control.

The agronomic efficiency was recorded higher at vermicompost followed by poultry manure. Islam and Munda (2012) reported that maize - toria system had higher economics at application of FYM $2.5 \mathrm{t} / \mathrm{ha+}$ Alnus $2.5 \mathrm{t} / \mathrm{ha}$ as compared to FYM $2.5 \mathrm{t} / \mathrm{ha}+$ Eupatorium 2.5 t ha. Mahesh et al., (2010) reported that combined application of recommended dose of NPK (150:75:40 kg/ha) + FYM 10 t/ha gave higher gross returns and B: C ratio, respectively followed by $75 \%$ recommended through nitrogen fertilizers and $25 \%$ nitrogen through poultry manure but the lowest gross returns and $\mathrm{B}$ : $\mathrm{C}$ ratio were noticed at 100 per cent recommended dose of NPK through chemical fertilizer (150:75:40 $\mathrm{kg} / \mathrm{ha}$ ). Parmasivan et al., (2006) reported that maize (COHM 5), fertilized with (250-76-88$7.4 \mathrm{~kg}$ N-P-K-Zn / ha) and (200-95-88-7.4 and 200-76-110-7.4 kg N-P-K-Zn / ha. The highest net returns and net $\mathrm{B}$ : $\mathrm{C}$ were obtained in treatment applied with 250-76-88. Somasundaram et al., (2007) reported that biogas slurry with Panchagavya had the highest net returns and benefit cost ratio than recommended dose of fertilizers and foliar sprays.

Site-specific nutrient management, recommended dose of fertilizer, FIRBS and ridge bed planting may enhance better productivity as well profitability of farmers against conventional planting in Indian scenario.

\section{References}

Abbas, H. K. and Bruns, H. A. 2005. Ultrahigh plant populations and nitrogen fertility effects on corn in the Mississippi Valley. Agron. J. 97(4): 1136.

Agriculture Research Data Book, ICAR, 2017 Akbar, F., Wahid, A., Akhtar, S., Ahmad, A. $\mathrm{N}$ and Chaudhary, F. M. 2002. Optimization of method and time of nitrogen application for increased nitrogen use efficiency and yield in maize. Pak. J. Bot. 3(1): 337-341.

Akbarnia, A., Alimardani, R. and Baharloeyan, S. 2010. Performance comparision of three tillage system in wheat farms. Australian. J. of Crop Sci. 4(8): 586-589.

Amanullah, K., Marwat, B., Shah, P., Maula, N. and Arifullah, S. 2009. Nitrogen levels and its time of application influence leaf area, height and biomass of maize planted at low and high density. Pak. J. Bot. 41(2): 761-768.

Arif, M., Jan, M. T., Khan, N. U., Akbar, H., Khan, S. A., Khan, M. J., Khan, A., Munir, I., Saeed, M. and Iqbal, A. 2010. Impact of plant populations and nitrogen levels on maize. Pak. J. Bot. 42(6): 3907-3913.

Ayub, M., Nadeem, M. A. and A. Tanveer. 2003. Influence of different nitrogen levels and harvesting times on dry matter yield and quality of fodder maize. Pak. J. Life Soc. Sci. 1: 59-61.

Bakht, J., Ahmad, S., Tariq, M., Akber, H. and Shafi, M. 2006. Response of maize to planting methods and fertilizer N. $J$. Agri. Bio. Sci. 1(3): 605-607.

Baloach, N., Yousaf, M., Akhter, W. P., Fahad, S. Ullah, B., Qadir G., and. Ahmed, Z. I. 2014. Integrated effect of phosphate solubilizing bacteria and humic acid physiomorphic attributes of maize International J. Curr. Microbiol. App. Sci. 3(6): 549-554. 
Bindhani, A., Barik, K. C. and Garnayak, L. M. 2007. Nitrogen management in baby corn (Zea mays). Indian J. Agron. 52(2): 135-138.

Biradar, D. P., Aladakatti, Y. R. and Basavanneppa, M. A. 2012. Enhancing the productivity and economics returns of field crops with balanced nutrient application through site specific nutrient management approach 146 AgroInformatics and Precision Agriculture 2012 (AIPA 2012)

Choudhary, V. K. and Kumar, P. S. 2013. Maize production, economics and soil productivity under different organic source of nutrients in eastern Himalayan region, India. International J. of Plant Prod. 2: 167-186.

Das, P. C. 2004. Plant nutrients in manures and fertilizers. $2^{\text {nd }}$ Ed. New Delhi, Kalyani publisher. 35p.

Das, S., Ghosh, G., Kaleem, M. D. and Bahadur, V. 2009. Effect of different levels of nitrogen and crop geometry on the growth, yield and quality of baby corn (Zea mays L.) cv. 'golden baby'. Acta Horti. 809: 161-166.

Garcia, J. R. S., Matocha, J. E. and Hons, F. M. 2006. Department of Soil and Crop Sciences, Texas Agricultural Experiment Station, Texas A\&M University.

Ghaffari, A., Ali, A., Tahir, Waseem, M. M., Ayub, M., Iqbal, A. and Mohsin, A. U. 2011. Influence of integrated nutrients on growth, yield and quality of maize. American J. of Plant Sci. 2: 63-69.

Goddard, T., zoebisch, M., Gaa, Ellis and Watlon, A. S 2008. No tillage farming system, world association on soil and water conservation. 39: 1

Govarts, B., Sayre, K. D. and Lichter, K. 1999. Influence of permanent raised bed planting and residue management on physical and chemical soil quality in rainfed maize/wheat system. Plant and Soil 291( 1-2): 39-54.
Gupta, V., Sharma, A., Kumar, J., Abrol, V., Singh, B. and Singh, M. 2014. Effect of integrated nutrient management on growth and yield of maize-gobi sarson cropping system in subtropical region under Foot Hills of North-West Himalyas. Bangladesh J. Bot. 43(2): 147-155.

Hakim, B., Helena, G. M. and Francisco, J. V. 2011. Permanent bed planting in irrigated mediterranean conditions: short-term effects on soil quality, crop yield and water use efficiency. An institute of Agricultural sustainable, department of Agronomy, Universidad de Córdoba, Spain.

Hammad, H. M., Ahmad, A., Azhar, F., Khaliq, T., Wajid, A., Nasim, W. and Farhad, W. 2011. Optimizing water and nitrogen requirement in maize ( $\mathrm{Zea}$ mays L.) under semi-arid conditions of Pakistan. Pak. J. Bot. 43(6): 2919-2923.

Haq, M. M. and Hamid, A. 1998. Effect of nitrogen on growth of intercropped maize and sweet potato. Indian J. Plant Physio. 3(4): 260-264.

Inman, D., Khosla, R. and Westfall, D. G. 2005. Nitrogen uptake across site specific management zones in irrigated corn production systems. Agrono. J. 97: 69- 176.

Irizar, A., Andriuo, A. and Mary, B. 2013. Long-term impact of no Tillage in two intensified crop rotations on different soil organic matter fractions in Argentine rolling pampa. The Open Agric. J. 7: 22-31

Islam, M. and Munda, G. C. 2012. Effect of organic and inorganifertilizer on growth, productivity, nutrient uptake and economics of maize and toria. Agric. Sci. Res. J. 2(8): 470-479.

Janwal, J. S. 2006. Effect of integrated nutrient management in maize on succeeding winter crops under rainfed 
conditions. Indian J. of Agron. 51 (1): 14-16.

Ji1, B., Zhao, Y., Mu, X., Liu, K. and Li, C. 2013. Effects of tillage on soil physical properties and root growth of maize in loam and clay in central China. Plant Soil Environ. 59(7): 295-302.

Kalhapure, A. H. Shete, B. T. and Dhonde. M. B. 2013. Integrated nutrient management in maize for increasing production with sustainability. International J. of Agric. and Food Scie. Tech. 4(3): 195-206.

Kannan, R. L., Dhivya, M., Abinaya, D., Krishna, R. L. and Kumar, S. K. 2013. Effect of integrated nutrient management on soil fertility and productivity in maize. Env. Pharmacol. Life Sci. 2 (8): 61-67.

Karami, A., Homaee, M. and Afzalina, S. H. S. 2012. Organic resource management impact of soil aggregate stability and soil physic-Chemi Properties. Agric. Environment. 148: 22-14.

Khan, H. Z., Malik, M. A. and Saleem, M. F. 2008. Effect of rate and source of organic material on the production potential of spring maize (Zea mays L.). Pak. J. Agricul. Sci. 45: 40-43.

Kumar, M., Hazarika, S., Choudhary, B. U., Ramesh. T., Verma, B. C. and Bordoloi, L. J. 2010. Liming and integrated nutrient management for enhancing maize productivity on acidic soils of Northeast India. Indian J. Hill Farming. 25(1): 35-37.

Kumar, V., Yashpal, S., Saharawat, M., Gathala, K., Jat, A. S., Singh, S. K., Chaudhary, N. and Jat, M. L. 2013. Effect of different tillage and seeding methods on energy use efficiency and productivity of wheat in the IndoGangetic Plains. Field Crops Res. 142: $1-8$.

Mahesh, L. C., Kalyanmurthy, K. N., Ramesha, Y. M., Shivakumar, K. M.,
Yogeeshappa, H. and Siddaram 2010. Effect of integrated nutrient management on nutrient uptake and economics of maize. International J. of Agriculture sci. 6: 327-329.

Majumdar, K., Jat, M. L., Pampolino, M., Dutta, S. and Kumar, A. 2013. Nutrient management in wheat.Current scenario, improved strategies and future research needs. Indian J. Wheat Res.4:1-10.

Mathew, R. P., Feng, Y., Githinji, L., Ankumah, R. and Balkcom, K. S. 2013. Impact of no- tillage and conventional tillage systems on soil microbial communities. J. of Applied and Environ. Soil Sci. 10(2): 161-166

Meena, S. R., Kumar A., Jat, N. K., Meena, B. P., Rana, D. S. and Idnani, L. K. 2012. Influence of nutrient sources on growth, productivity and economics of baby corn (Zea mays)-mungbean (Vigna radiata) cropping system. Indian $J$. Agron. 57(3) 217221.

Memon, S. Q., Mirjat, M. S., Mughal A. Q. and Amjad N. 2013. Effect of conventional and non-conventional tillage practices on maize production. Pak. J. Agri. 29 (2): 155-163.

Mohanty, M., Painuli, D. K., Misra A. K., Bandyopadhyaya K. K. and Ghosh P. K. 2006. Estimating impact of puddling, tillage and residue management on wheat ( $T$. aestivum L.) seedling emergence and growth in a rice wheat system using nonlinear regression models. Soil and Tillage Research, 87: 119-130.

Moraru, P. I., Rusu, T., Bogdan, I., POP, A. I. and Lucia, M. 2010. Sopterean effect of different tillage system on soil properties and production on wheat, maize and soyabean crops. seria $J$. Agron. 54: 258-261.

Nadeem, M. A., Iqbal, Z., Ayub, M., Mubeen, K. and Ibrahim, M. 2009. Effect of nitrogen application on forage yield and 
quality of maize sown alone and in mixture with legumes. Pak. J. Life Soc. Sci. 7(2): 161-167.

Nagavani, A. V. and Subbian, P. 2014. Productivity and economics of hybrid maize as influenced by integrated nutrient management. Current Biotica. 7(4): 283-293.

Naresh, R. K., Singh, B., Singh, S. P., Singh, P. K., Kumar, A. and Kumar, A. 2012. Effect of furrow irrigated raised bed planting technique for diversification of rice-wheat system for western IGP Region. International J. Life Sci. Bt and Pharm. Res. 2012.

Nsanzabaganwa, E., Das, T. K., Rana, D. S. and Kumar S. N. 2014. Nitrogen and phosphorus effects on winter maize in an irrigated agroecosystem in western Indo-Gangetic plains of India Maydica electronic publication 59: 152-160.

Nwite, J. N., lgboji, P. O. and Okonkwo, G. I. 2014. Effect of Integrated Nutrient Management on selected soil physical properties and grain yield of maize in Abakailiki, South eastern Nigeria J. of Agril. Econ. Exten. and Rural. Dev. 2(11): 211-217.

Oktem, A., Oktem, A. G. and Emeklier, H. Y. 2010. Effect of nitrogen on yield and some quality parameters of sweet corn. Communications in Soil Sci. Plant Analysis 41(7): 202-204.

Onasanya, R. O., Aiyelari, O. P., Onasanya, A., Oikeh, S., Nwilene, F. E and Oyelakin, O. O. 2009. Growth and yield response of maize to different rates of nitrogen and phosphorus fertilizers in southern Nigeria. World J. Agricul. Sci. 5(4): 400-407.

Pandey, A. K., Ved, P., Mani, V. P. and Singh, R. D. 2000. Effect of rate of nitrogen and time of application on yield and economics of baby corn. Indian J. Agrono. 45(2): 338-343
Paramasivan, M., Malarvizhi, P. and Thiyageswari, S. 2012. Balanced use of inorganic fertilizers on maize yield, nutrient uptake and soil fertility in alfisols. Karnataka J. Agric. Sci. 25 (4): 423-426.

Pompolino, M. F., Witt, C., Pasuquin, J. M., Tuhniton, A. and Fisher, M. J. 2012. Development approach and evaluated of the nutrient expert left water for nutrients management in wheat crops Election. Agric -888. 103 Nitrogen and food productivity in India. International J. of Agric. Sci. 7: 66-62.

Randhawa M. S., Maqsood M., Wajid Syed. A. and Haq, M. A. 2012. Effect of integrated nutrient plant nutrition and irrigation scheduling on yield and yield components of maize. Pak. J. Agri. Sci., 49(3): 267-273.

Rehman, A. M., Saleem, F., Safdar, M. E., Hussain, S. and Akhtar, N. 2011. Grain quality, nutrient use efficiency, and bioeconomics of maize under different sowing methods and NPK levels. Chilli J. Agric. Res. 71(4): 12-16.

Sarwar M., Jilani G., Rafique, E., Akhtar M. E. and Chaudhry A. N. 2012. Impact of integrated nutrient management on yield and nutrient uptake by maize under Rain-fed conditions. Pakistan J. of Nutrition. 11(1): 27-33.

Sen, D., Singh, R. and Shyam, R. 2002. Efficacy of tillage and weed management practices on weed infestation and yield of wheat. Indian J. of Weed Sci. 42(1\&2): 57-61.

Senjobi, B. A., Olufunmilayo, T. A. and Okulaja, A. E. 2013. Effects of tillage practices on soil properties under maize cultivation on Oxic Paleustalf in South Western Nigeri. Open J. of Soil Sci. 3: 163-168.

Shah, R. A. and Kumar, S. 2014. Direct and residual effect of integrated nutrient management and economics in hybrid 
rice-wheat cropping system. AmericanEurasian J. Agric. \& Environ. Sci. 14(5): 455-458.

Shilpashree, V. M., Chidanandappa, H. M., Jayaprakash, R and Punitha, B. C. 2012. Effect of integrated nutrient management practice on distribution of nitrogen fraction by maize crop in soil. Indian J. of Fundamental and Applied Life Sci. 2 (1): 38-44.

Singh, B., Kular, J. S. and Mandal, M. S. 2014. Relative abundance and damage of some insect-pest of wheat under different tillage practice in rice-wheat cropping in India. Crop Protection. 61:16-22

Singh, G., Sharma, G. L. and Shankar. 2012. Effect of integrated nutrient management on quality protein maize. Crop Res. 44 (1 \& 2): 26-29.

Singh, M. K., Singh, R. N., Singh, S. P., Yadav, M. K. and Singh, V. K. 2010. Integrated nutrient management for higher yield, quality and profitability of baby corn (Zea mays). Indian $J$. Agrono. 55(2): 100-104.

Somasundaram, E., Amanullah, M. M., Vaiyapuri, K., Thirukkumaran, K. and
Sathyamoorthi K. 2007. Influence of organic sources of nutrients on the yield and economics of crops under maize based cropping system. J. of Applied Sci. Res. 3(12): 1774-1777.

Tolessa, D., Preez, C. C. and Ceronio, G. M. 2000. Effect of tillage system and nitrogen fertilization on efficacy of applied nitrogen by maize in Western Ethiopia. S. Afr. J. Plant Soil 26(1): 211-214.

Wasaya, A., Tahir, M., Tanveer, A. and Yaseen, M. 2011. Response of maize to tillage and nitrogen management. The $J$. Animal \& Plant Sci. 22(2): 452-456.

Yadav, A. K., Chand, S. and Thenua, O. V. S. 2016. Effect of integrated nutrient management on productivity of maize with mungbean intercropping. Global. J. of Bio-Scie. Biotec. 5(1): 115-118.

Yadav, S. K., Babu, S., Singh. Y., Yadav, M. K., Yadav, G. S., Pal, S., Singh, Y. and Singh, K. 2005. Effect of organic nutrient sources on yield, nutrient uptake and soil biological properties of rice (Oryza sativa)-based cropping sequence. Indian J. of Agron. 58(3): 271-276.

\section{How to cite this article:}

Amrendra Kumar and Sunil Kumar. 2018. A Review on Impact of Tillage and Nutrient Management on Maize Production in Indian Scenario. Int.J.Curr.Microbiol.App.Sci. 7(09): 583-594. doi: https://doi.org/10.20546/ijcmas.2018.709.069 